\title{
Sebaceous Carcinoma of the Vulva: An Unexpected Diagnosis and Literature Review
}

\section{Carcinoma Sebáceo da Vulva: Um Diagnóstico Inesperado e Revisão da Literatura}

Ana Carolina ROCHA ${ }^{1}$, Maria Inês SÁ2, Carlos ABRANTES ${ }^{3}$, Rita SOUSA ${ }^{4}$

Acta Med Port 2022 Jan;35(1):63-67 • https://doi.org/10.20344/amp.13551

\section{ABSTRACT}

Sebaceous carcinoma of the vulva is a rare malignancy of the sebaceous glands, with potentially aggressive behaviour, that is usually found in the peri-ocular area. Nonetheless, there are sebaceous glands in the vulva and this diagnosis is especially rare, with only ten cases described in the literature. We report a case of 78-year-old female patient who presented with vulvar pruritus, previously treated with topical steroid and antifungal treatments, without improvement. The vulvar examination showed a visible yellow papule, $12 \times 10$ $\mathrm{mm}$ on the right major labia, which was biopsied and the microscopic examination revealed an invasive sebaceous carcinoma of the vulva, with an in situ component. We performed an uneventful excisional biopsy, followed by a subsequent margin widening. Three months after the diagnosis, she presented with the first recurrence. Two and half years after the diagnosis, she recurred with a larger lesion $(13 \mathrm{~mm}$ ) in the upper half of small right lip, more than $10 \mathrm{~mm}$ away from the midline. In a multidisciplinary meeting it was decided that the patient should undergo partial right vulvectomy with homolateral inguino-femoral sentinel node biopsy (one negative node). There was no evidence of recurrence one-year post-surgery.

Keywords: Sebaceous Gland Neoplasms; Vulva; Vulvar Neoplasms

\section{RESUMO}

O carcinoma sebáceo da vulva é uma neoplasia maligna rara das glândulas sebáceas com comportamento potencialmente agressivo, mais comummente encontrada na área periocular. Este diagnóstico é particularmente raro nas glândulas sebáceas da vulva, com apenas dez casos previamente descritos na literatura. Relatamos o caso de uma paciente de 78 anos que se apresentou com prurido vulvar, anteriormente tratado com corticóides tópicos e antifúngicos, sem melhoria evidente. Ao exame objetivo apresentava uma pápula amarela visível, com cerca de $12 \times 10 \mathrm{~mm}$ no grande lábio direito, que foi biopsada. O exame microscópico revelou um carcinoma sebáceo invasivo da vulva, com componente in situ. Posteriormente, foi realizada uma biópsia excisional, com alargamento de margens, sem intercorrências. Três meses após o diagnóstico, surgiu a primeira recidiva, pelo que foi realizada uma nova biópsia excisional. Dois anos e meio após o diagnóstico, a doente apresentava uma lesão com $13 \mathrm{~mm}$, na metade superior do pequeno lábio direito, mais de $10 \mathrm{~mm}$ afastada da linha mediana. Em reunião multidisciplinar decidiu-se que deveria ser submetida a uma vulvectomia parcial direita, com pesquisa de gânglio sentinela inguino-femoral homolateral (um gânglio negativo). Um ano após a cirurgia, a doente encontra-se sem evidência de recorrência.

Palavras-chave: Neoplasias das Glândulas Sebáceas; Neoplasias Vulvares; Vulva

\section{INTRODUCTION}

Sebaceous carcinoma (SC) of the vulva is a rare malignancy of the sebaceous glands with potentially aggressive behaviour. Sebaceous carcinoma is most commonly found in the periocular area. Extra ocular vulvar SC is particularly rare, with ten cases described in the literature. ${ }^{1}$ Due to limited data, little is known about the appropriate management and prognosis of vulvar SC. Reported risk factors for SC in general include advanced age, women of Asian or South Asian ethnicity, previous irradiation, genetic predisposition for Muir-Torre syndrome or possibly familial retinoblastoma. ${ }^{2-4}$

The most confusing aspect of vulvar SC is the myriad of clinical presentations, but it can be frequently described as yellow-tan nodules, with various sizes and ulcerated. We present a case of a recurrent vulvar SC.

\section{CLINICAL CASE}

A 78-year-old Caucasian woman, gravida 1 para 1 , menopause at 45-years of age, presented to Instituto Português de Oncologia de Coimbra (IPOC) with chronic vulvar pruritus. She had been previously treated with topical steroids and antifungals, without improvement. She denied other symptoms such as pain, vaginal bleeding, ulceration, discharge or dysuria.

The patient had a previous history of significant hypertension, hypothyroidism, arthritis, type 2 diabetes and anxiety. She had no other relevant gynaecologic history and no family history of known malignancies.

At physical examination, she presented with a small yellow papule in the major right lip, $10 \times 12 \mathrm{~mm}$, with a reddish ridge. No inguinal adenopathies were noticeable. We performed a biopsy in which the histopathological examination showed a vulvar invasive SC with an intraepithelial component. The genetic test for Muir-Torre syndrome and HPV were negative. Two months after the diagnosis she underwent an uneventfully excisional biopsy, with

1. Serviço de Ginecologia-Obstetrícia. Hospital de Santarém. Santarém. Portugal.

2. Serviço de Ginecologia-Obstetrícia. Hospital de Vila Real. Vila Real. Portugal.

3. Serviço de Anatomia Patológica. Instituto Português de Oncologia de Coimbra. Coimbra. Portugal.

4. Serviço de Ginecologia. Instituto Português de Oncologia de Coimbra. Coimbra. Portugal.

$\square$ Autor correspondente: Ana Carolina Rocha. carolinarch14@gmail.com

Recebido: 05 de fevereiro de 2020 - Aceite: 20 de novembro de 2020 - Online issue published: 03 de janeiro de 2022 Copyright $\odot$ Ordem dos Médicos 2022 


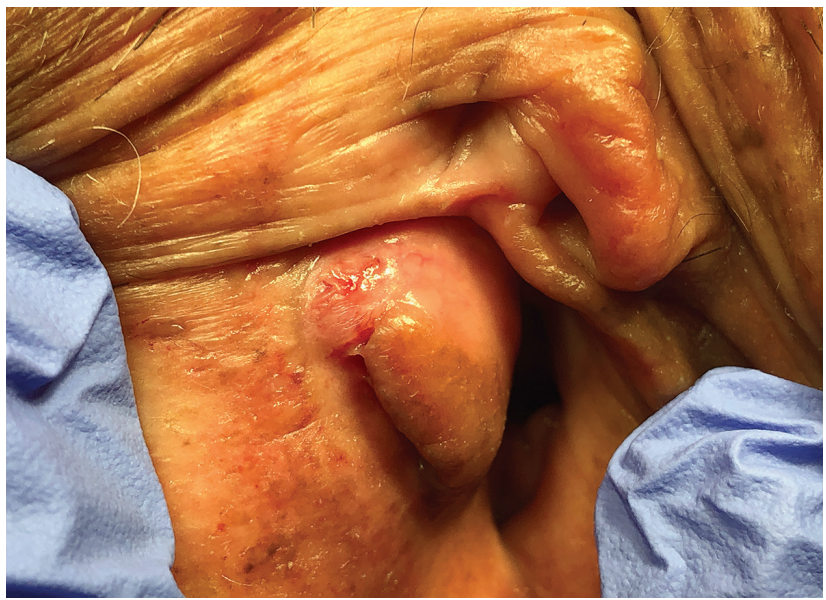

Figure 1 - Ulcerated nodule with approximately $10 \mathrm{~mm}$ in the small right lip

subsequent margin widening due to insufficient margins. She was discharged from the hospital disease-free. The patient was followed up on in an outpatient clinic, with no signs of persistent disease or relapse.

Three months after the initial diagnosis, she presented with newly onset pruritus and an ulcerated papule. The biopsy confirmed a local recurrence. She underwent another excisional biopsy and maintained regular outpatient followup.

Two and half years after the second surgery, she presented with an ulcerated nodule with approximately $13 \mathrm{~mm}$ in the upper half of small right lip, more than $10 \mathrm{~mm}$ away from the midline (Fig. 1). The biopsy confirmed another local recurrence of the initial diagnosis. A full body computed tomography scan showed no evidence of distant metastatic disease or any other malignant neoplasm.

After a multidisciplinary discussion with the presence of the patient, we performed a partial right vulvectomy with homolateral inguino-femoral sentinel node biopsy (one negative lymph node) (Fig. 2). Two weeks after the surgery, she presented with wound dehiscence in the groin area, which was re-sutured. The patient received no adjuvant therapy and one year after the last surgical intervention, she was healing well without signs of recurrence.

On histopathological examination, the first vulvar biopsy showed a well differentiated SC, characterized by a proliferation of neoplastic cells with sebaceous differentiation, showing multivesicular cytoplasmic clearing and nuclear scalloping (clearly different from simple cytoplasmic clearing) (Fig. 3A), with moderate nuclear pleomorphism and significant mitotic activity [10 mitoses / 10 high power field (HPF)]. The tumour grew in lobules of variable dimension, invading the dermis in an expansive pattern, some appearing to have a connection with the epidermis (Fig. 3B) and was considered grade I. Moreover, some of the neoplastic cells were present inside the epidermis, in small aggregates or with a pagetoid distribution, which was interpreted as an in-situ (intraepithelial) component (Fig. 3C). The neoplastic cell showed diffuse immunoreactivity for cytokeratin (CK) 7 , CK 8/18, androgen receptor (AR) and Ber-Ep4; immunos-
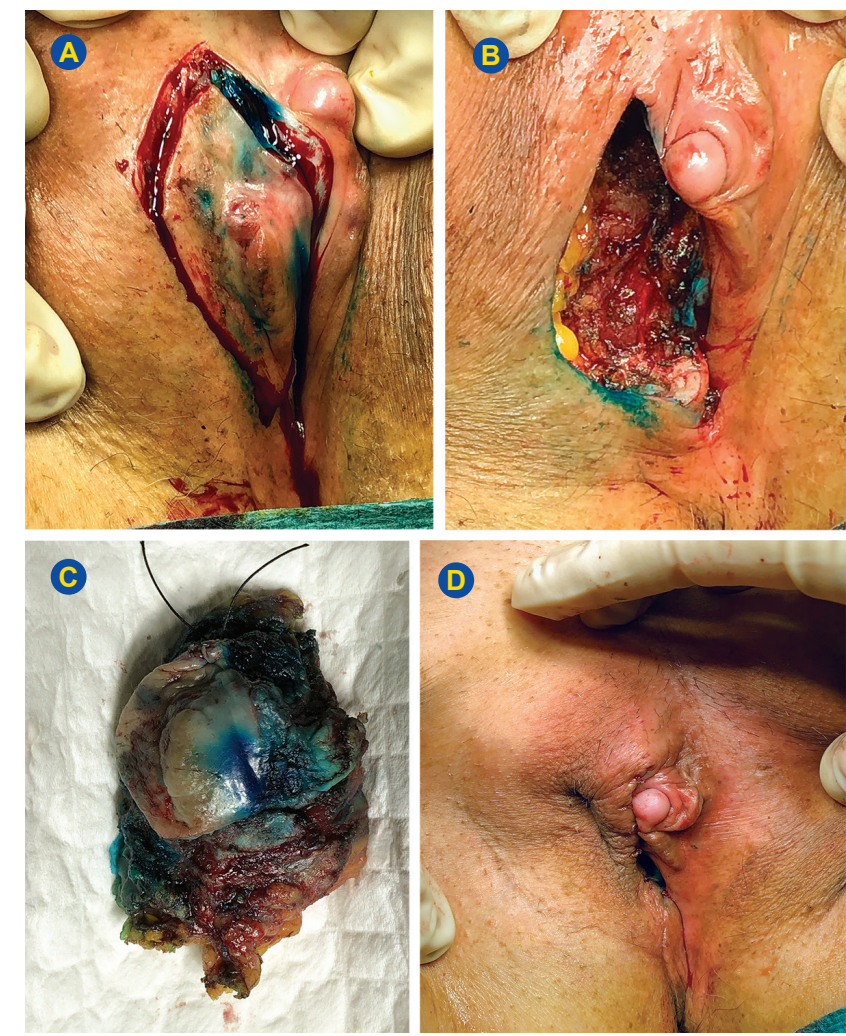

Figure 2 - A and B - partial right vulvectomy; C - surgical piece of right vulvectomy; D - surgical closure
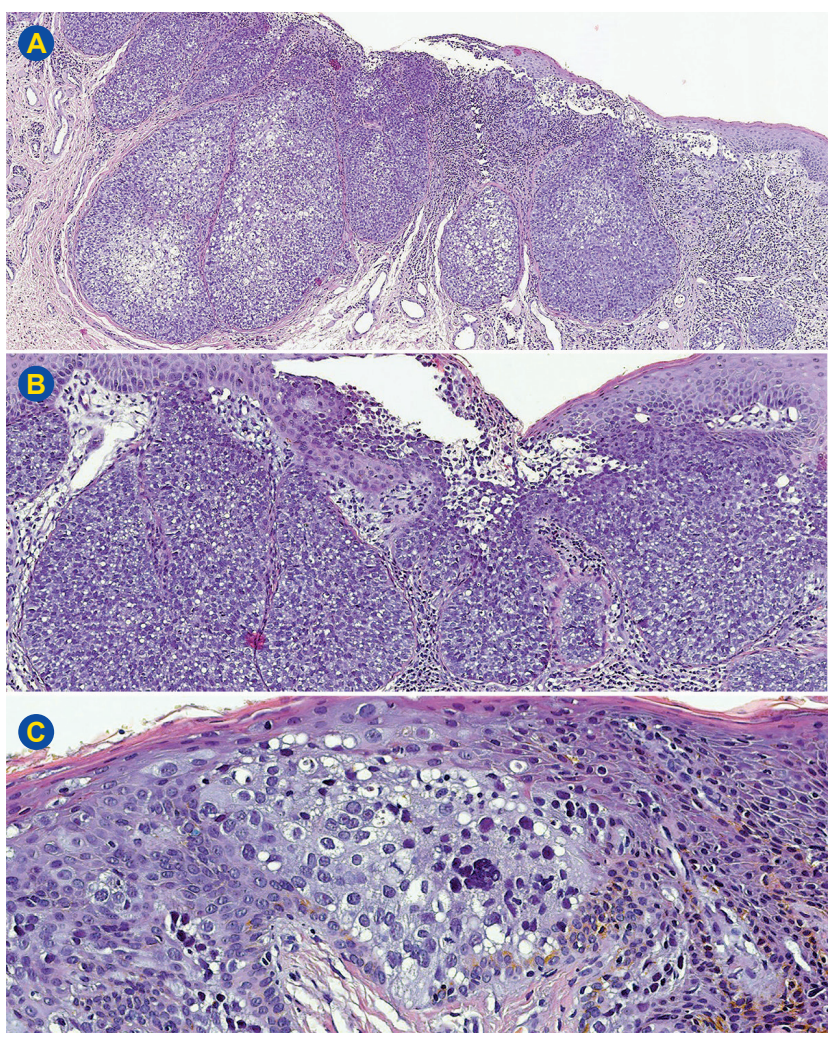

Figure 3 - First biopsy, microscopy: The tumor grew in lobules of variable dimension, invading the dermis in an expansive pattern $(A)$, some appearing to have a connection to the epidermis (B). Some of the neoplastic cells were present inside the epidermis, in small aggregates or with a pagetoid distribution, which we interpreted as an in-situ (intraepithelial) component (C). 

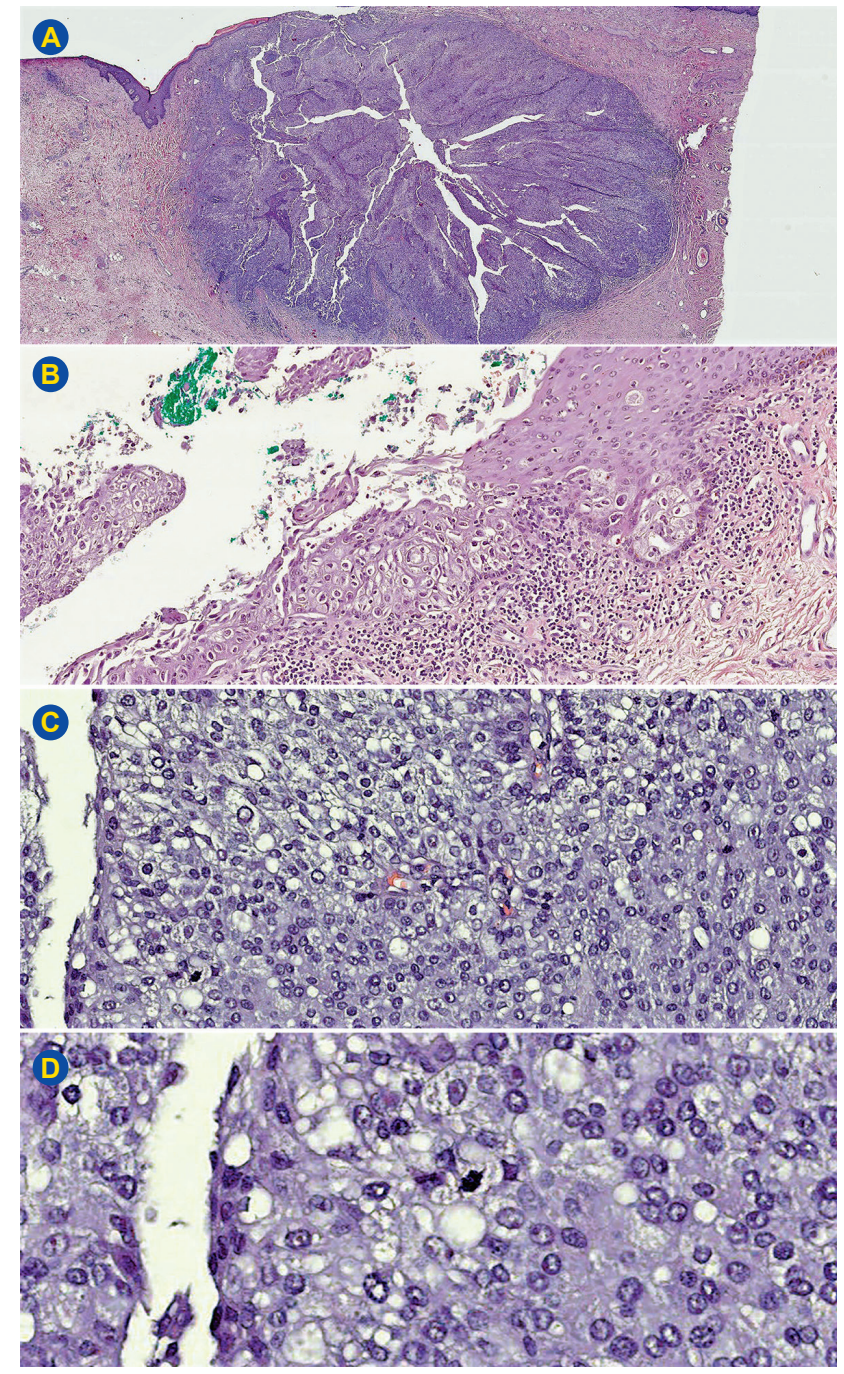

Figure 4 - Partial right vulvectomy, microscopy: a recidivated sebaceous carcinoma was observed, less differentiated than the previous excisions. It retained the same lobular growth pattern, with an expansive type of invasion (A); as before, focal in-situ growth was also observed (B). The neoplastic cells displayed evident nuclear pleomorphism and high mitotic activity with atypical mitosis; the cytoplasms were clear or granular, with cytoplasmic microvacuolization less common (C and D).

taining for epithelial membrane antigen (EMA) was focally positive, enhancing the cytoplasmic vacuolization of the tumour cells. The surgical margins appeared clear, but with a minimum distance to the neoplasm of only $0.3 \mathrm{~mm}$.

Both the second incisional biopsy and the re-excision specimen, showed a SC with the same histopathological morphology as the first lesion, including the in-situ component. The surgical margins appeared clear once again, but with a minimum distance to the neoplasm of only $0.48 \mathrm{~mm}$.

In terms of the right vulvectomy (Fig. 4), the histopathological examination of the surgical specimen showed a relapsed SC, less differentiated than the previous excisions (Fig. 3). It retained the same lobular growth pattern, with an expansive type of invasion (Fig. 4); as before, and focal in-situ growth was also observed. The neoplastic cells displayed evident nuclear pleomorphism and high mitotic activity with atypical mitosis (21 mitoses / $10 \mathrm{HPF}$ ); the cytoplasm was clear or granular, with cytoplasmic microvacuolation less common (Fig. 4). The immunohistochemical tests yielded similar results, with the neoplastic cells maintaining immunoreactivity for AR, EMA, Ber-Ep4 and CK8/18 (focal); however, CK7 was negative (Fig. 5).

\section{DISCUSSION}

Ten previous cases of vulvar SC have been published to date in the literature and were similarly treated with surgical excision. Nonetheless, some were treated also with radiotherapy and/or quimotherapy. ${ }^{1}$ It is estimated that the presence of SC in the genitals is approximately $1.1 \%$ of all SC. ${ }^{3}$ Extra ocular SC was once thought to be highly aggressive, but recent reports suggest similar prognosis for both ocular and extra ocular disease., ${ }^{3,5}$ Apart from the different clinical characteristics and the types of surgical treatment of the previous cases, the overall prognosis is favourable, with only one patient deceased. ${ }^{6}$ These neoplasms appear to have a $30 \%-40 \%$ risk of local tumour recurrence, a $20 \%-25 \%$ risk of distant metastases and a $10 \%-20 \%$ risk of tumour-related mortality. ${ }^{1}$

The pathogenesis of extra ocular SC remains poorly understood. There are no cases of HPV infection and only two cases presented with a strong family history suggesting possible Muir-Torre syndrome (an autosomal dominant disorder, a subgroup of hereditary nonpolyposis colorectal cancer associated with some SC). ${ }^{7,9}$ Therefore, it is important to have genetic counselling due to this known association, which was non-existent in our patient.

Unlike ocular SC, little is known about prognostic factors in vulvar SC. Older age, higher grade tumours and distant metastasis have been described as poor prognostic factors, but lymph node metastasis have not been described as an independent prognostic factor for SC of the head and neck. ${ }^{2,10}$ Limited information is available in the literature regarding lymphovascular space invasion and depth of invasion, with only one previous case that reported distant metastasis with metastatic disease in the lung published. ${ }^{6}$ There is variable and inconclusive information about the relationship between the tumour size and the positive node status. ${ }^{7,8,11}$

Of the ten cases previously described, five women underwent inguinal lymphadenectomy with three of them having positive lymph nodes ${ }^{1,7}$; such was not the case in our patient, who had a negative sentinel lymph node and therefore lymphadenectomy was not performed. The two patients described who had lymph node metastasis received adjuvant radiotherapy $(\mathrm{RT})$, with only one having a recurrence of disease within the time frame of follow-up. ${ }^{7,11}$ Our patient is the first one with negative lymph node metastasis, but with a recurrence of the disease. Due to the rarity of this disease, the optimal treatment still unknown. However, all authors find it reasonable to consider surgery to be the adequate initial intervention, with the goal aim being complete excision of the disease. In the largest series of SC (ocular and extra ocular), ${ }^{3}$ only $5.3 \%$ of the patients received RT. It is 


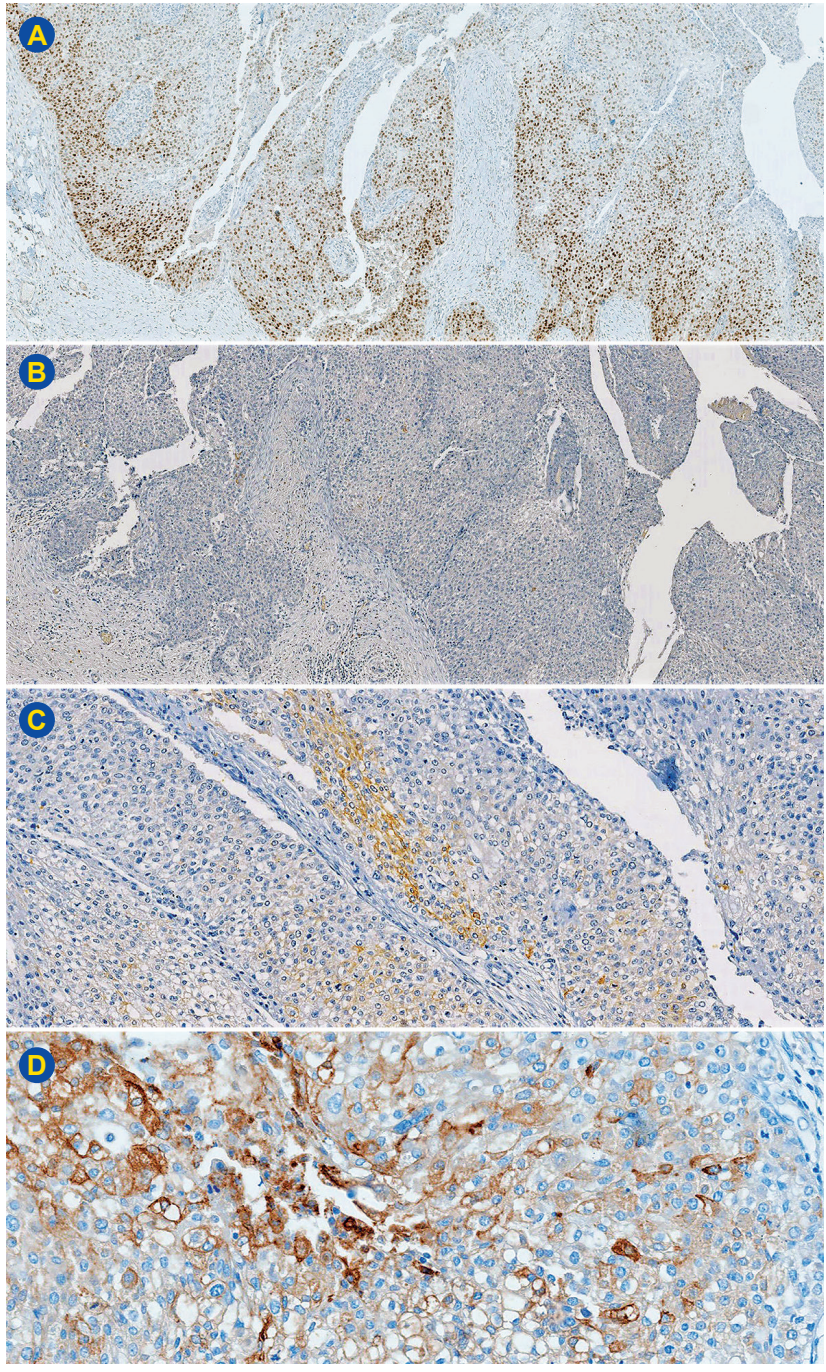

Figure 5 - Partial right vulvectomy, microscopy: the neoplastic cells maintained immunoreactivity for AR (A); however, CK7 was negative (B). CK8/18 was focally positive (C) and EMA was also positive, being harder to observe the microvacuolization of the cytoplasms (D), compared to the first biopsy.

reasonable to consider adjuvant therapy, such as RT, with positive lymph node metastasis; however, there is little information guiding this practice.

In summary, the vulva is a rare primary location for SC, which appears to have many clinicopathological differences when compared to the classic disease. As far as we know, our case is the first one with an intraepithelial/in-situ component. It is important to recognize and make the appropriate diagnosis of these rare tumours in order to better understand the natural history of this disease.

\section{ACKNOWLEDGMENTS}

We would like to thank to Sofia Raposo, Paulo Correia, Paulo Aldinhas e Luis Sá for the help and encouragement to write this article.

\section{AUTHORS CONTRIBUTION}

ACC: Data acquisition and interpretation, draft of the manuscript, wrote the final version of the paper.

MIS: Data acquisition and interpretation, critical review and approval of the final version of the paper.

CA: Conception and analysis of anatomopathological information, critical review and approval of the final version of the paper.

RS: Data acquisition and interpretation, critical review and approval of the final version of the paper

\section{PROTECTION OF HUMANS AND ANIMALS}

The authors declare that the procedures were followed according to the regulations established by the Clinical Research and Ethics Committee and to the Helsinki Declaration of the World Medical Association updated in 2013.

\section{PATIENT CONSENT}

Obtained.

\section{DATA CONFIDENTIALITY}

The authors declare that they followed the protocols in use at their working center regarding patients' data publication. Patient consent obtained.

\section{COMPETING INTERESTS}

The authors declare that there are no competing interests.

\section{FUNDING SOURCES}

No subsidies or grants contributed to this work.

\section{REFERENCES}

1. Thakur BK, Verma S, Khonglah Y, Jitani A. Multifocal sebaceous carcinoma of the vulva. Dermatol Venereol Leprol. 2017;83:221-4.

2. Sullivan S, Tran A, O'Connor S, Gehrig P. Sebaceous carcinoma of the vulva: a case report and review of the literature. Gynecol Oncol Rep. 2016;18:40-1.

3. Dasgupta T, Wilson LD, Yu JB. A retrospective review of 1349 cases of sebaceous carcinoma. Cancer. 2009;115:158-65.

4. Ponti G, Losi L, Di Gregorio C, Roncucci L, Pedroni M, Scarselli A, et al., Identification of Muir-Torre syndrome among patients with sebaceous tumors and keratoacanthomas: role of clinical features,microsatellite instability, and immunohistochemistry. Cancer. 2005;103:1018-25.

5. Moreno C, Jacyk WK, Judd MJ, Requena L. Highly aggressive extraocular sebaceous carcinoma. Am. J. Dermatopathol. 2001;23:4505 .
6. Ikuse S, Jinbou A, Matsushima I. A case of sebaceous carcinoma. Jpn J Dermatol. 1976;B86:783.

7. Khan Z, Misra G, Fiander AN, Dallimore NS. Sebaceous carcinoma of the vulva. BJOG. 2003;110:227-8.

8. Carlson JW, McGlennen RC, Gomez R, Longbella C, Carter J, Carson LF. Sebaceous carcinoma of the vulva: a case report and review of the literature. Gynecol Oncol. 1996;60:489-91.

9. Escalonilla P, Grilli R, Canamero M, Soriano ML, Fariña MC, Manzarbeitia $\mathrm{F}$, et al. Sebaceous carcinoma of the vulva. Am J Dermatopathol. 1999;21:468-72.

10. Jacobs DM, Sandles LG, Leboit PE. Sebaceous carcinoma arising from Bowen's disease of the vulva. Arch Dermatol. 1986;122:1191-3.

11. Kawamoto M, Fukuda Y, Kamoi S, Sugisaki Y, Yamanaka N. Sebaceous carcinoma of the vulva. Pathol Int. 1995;45:767-73. 
12. Thomas WW, Fritsch VA, Lentsch EJ. Population-based analysis of prognostic indicators in sebaceous carcinoma of the head and neck. Laryngoscope. 2013;123:2165-9.

13. Pusiol T, Morichetti D, Zorzi MG. Sebaceous carcinoma of the vulva: critical approach to grading and review of the literature. Pathologica. 2011;103:64-7.

14. Rulon DB, Helwig EB. Cutaneous sebaceous neoplasms. Cancer. 1974;33:82-102. 